MINERALOGIA POLONICA

DOI 10.2478/v10002-007-0018-5

PL ISSN 0032-6267

Vol. 38, No 1, 2007

Arkadiusz DERKOWSKI ${ }^{1,2}$, Marek MICHALIK ${ }^{2}$

\title{
STATISTICAL APPROACH TO THE TRANSFORMATION OF FLY ASH INTO ZEOLITES
}

\author{
Received Januaty 11, 2006; accepted September 01, 2006
}

A b s t r a ct. The experimental conversion of F-class fly ash into zeolites is described. The ash, composed mainly of aluminosilicate glass, mullite and quartz, was collected in the Cracow power plant (southern Poland). The experiments involved the heating of fly ash samples in PTFE vessels. Time, temperature and solution composition were the reaction parameters considered in the experiments and in the subsequent modeling. A series of reactions with $0.5,3$ and $5 \mathrm{M} \mathrm{NaOH}$ solutions (and some with additional $3 \mathrm{M} \mathrm{NaCl}$ ) were carried out at $70^{\circ}, 100^{\circ}$ and $150^{\circ} \mathrm{C}$ for $12-48$ hours under autogenic pressure (not measured) and at a constant ash-to-solution ratio of $33.3 \mathrm{~g} / \mathrm{l}$. The following zeolite phases were synthesized: sodalite (SOD structure), hydroxysodalite (SOD), CAN type phases, Na-X (FAU), and NaP1 (GIS). Statistically calculated relationships based on the mineral- and chemical compositions of the reaction products support the conclusion that the type of zeolite phase that crystallizes depends on the concentration of $\mathrm{OH}^{-}$and $\mathrm{Cl}^{-}$ in solution and on the temperature of the reaction. The duration of reaction, if on the order of tens of hours, is of less significance. The nature of the zeolite phase that crystalises is controlled by the intensity and selectivity of the substrate dissolution. That dissolution can favour, in sequence, one or other of the components in the substrate, resulting in $\mathrm{Si} / \mathrm{Al}$ variation in the reaction solutions. Mullite dissolution (decreasing solution $\mathrm{Si} / \mathrm{Al}$ ) characterizes the most advanced reaction stages. The sequence of crystallization of the zeolite phases mirrors the sequential dissolution of substrate components, and the composition of the crystallizing zeolite crystals reflects the changes in the solution $\mathrm{Si} / \mathrm{Al}$.

Key-words: fly ash, zeolite synthesis, mechanism of transformation

\section{INTRODUCTION}

The problems of deposition and utilization of coal combustion wastes become more serious every year. Fly ash is the finest solid fraction produced during the combustion of coal in power plants. Fly ash, transported by the gases from a combustion chamber, is trapped on electrostatic filters and deposited in reservoirs and on dumps. From these, it may be dispersed by winds to pollute air, soil and water. The finest ash fractions show

1 Institute of Geological Sciences, Polish Academy of Sciences, Senacka 1, 31-002 Kraków, Poland.

2 Institute of Geological Sciences, Jagiellonian University, Oleandry 2a, 30-063 Kraków, Poland. 
high contents of toxic elements. Heavy metals, due to their weak bonding in aluminosilicate glass, can be leached by meteoric water from fly ash (Yan, Neretnieks 1995). The negative impact of this process on local ecosystems has been noted (Tyson 1997).

The mineral composition of fly ash depends on the content and composition of mineral matter in coal and on the technology of combustion. The main components of F-class fly ash (see classification of Manz 1999) are aluminosilicate glass, mullite, quartz and residual coaly matter. Carbonates, Fe-oxides, sulphates, feldspars, tridymite and cristoballite are minor components (Querol et al. 1995; Wilczyńska-Michalik, Michalik 1996; Chang, Shih 1998; Ratajczak et al. 1999).

The neutralization or utilization of fly ash is an increasing factor in the cost of energy production. Fly ash is widely used as a component in materials for the building industry, in mining as backfill, in soil fertilization (Amrhein et al. 1996) and as an inexpensive sorbent of water pollutants (Hari Babu et al. 1993; Queralt et al. 1997; Sarbak, Kramer-Wachowiak 1998, 2002).

The high contents of silica and alumina in fly ash, and the presence of high temperature phases, facilitates the transformation of ash into zeolites and related aluminosilicates during treatment by alkaline hydroxide solutions. The laboratory hydrothermal synthesis of low-Si zeolites is similar to the natural processes of basaltic glass alteration (Wirsching 1981; Kawano, Tomita 1997; Christidis et al. 1999). Research on the synthesis of zeolite phases from post-combustion wastes has been carried out in many countries. Many zeolite phases have been obtained through the hydrothermal transformation of fly ash, e.g., NaP1, sodalite, faujasite, analcime, nepheline hydrate, hydroxycancrinite, phillipsite, F Linde, and others (Berkgaut, Singer 1996; Querol et al. 1997, 2002; Ma et al. 1998; Hollman et al. 1999). However, only a few of these studies focused on the systematics of fly ash transformation under alkali conditions.

Fly ash from power plants in Cracow (Poland) was examined in the past as a potential substrate for zeolite synthesis. Several zeolite phases (sodalite and hydroxysodalite, NaP1, faujasite, cancrinite and chabasite) were obtained during hydrothermal syntheses in experiments lasting from ten hours to seven days (Michalik, Wilczyńska-Michalik 1998; Derkowski 2001, 2002a). In this present study, three aspects were investigated:

- The differentiation of zeolite products as a function of composition and concentration of solutions, temperature and duration of reaction.

- The limits of the crystallization fields of the zeolite minerals obtained.

- The development of models for fly ash transformation under alkali hydrothermal conditions.

\section{MATERIALS}

The fly ash samples were collected from fresh ash reservoirs at the Elektrocieptownia Kraków power plant (Cracow, Poland). The samples comprise (aluminosilicate glass (40$-50 \%)$, mullite $(<30 \%)$, quartz $(5-7 \%)$, unburnt coaly matter ( $<7.26 \%$ - LOI limit) with Fe oxides, gypsum, calcite, feldspars and apatite as minor components (Derkowski 2002a). 


\section{METHODS}

\section{Experimental methods}

Syntheses were performed in an autoclave using alkaline solutions under the following conditions. Sample $-500 \mathrm{mg}$ of ground and homogenized ash. Solutions $-15 \mathrm{ml}$ $\mathrm{NaOH}$ solution $(0.5,3$ and $5 \mathrm{M})$ or a mixture of $10 \mathrm{ml} \mathrm{NaOH}$ solution and $5 \mathrm{ml} 3 \mathrm{M} \mathrm{NaCl}$ solution (see Tables 1 and 2). Ash/solution ratio - constant solid to liquid ratio of $33.3 \mathrm{~g} / \mathrm{l}$. Equipment - autoclave with 6 PTFE vessels of $30 \mathrm{ml}$ capacity not equipped with temperature - or pressure control instruments. Reaction times - 12, 24, 36 and 48 hours in 12 -hour heating/cooling cycles. Reaction temperatures $-70^{\circ} \mathrm{C}, 100^{\circ} \mathrm{C}, 150^{\circ} \mathrm{C}$ (furnace setting). Pressure - autogenic in reaction vessels. Treatment after reactions each sample washed with distilled water and dried. Technical details for separate samples are given in Tables 1 and 2.

\section{Analytical methods}

Mineral compositions were determined by X-ray diffraction (XRD) using a Philips X'pert APD diffractometer with PW 3020 goniometer, $\mathrm{Cu}$ tube and graphite curved crystal monochromator. Phase identification involved use of the JCPDS-ICDD database linked to the Philips X'Pert software and the ClayLab program, version 1 (K. Mystkowski, personal communication). Semi-quantitative mineral analysis was based on the intensity of XRD peaks over background. All XRD measurements were carried out under identical conditions. Preparations involved sedimentation of $200 \mathrm{mg}$ of sample ground in a mortar (fraction $<20 \mu \mathrm{m}$ ) on frosted glass. Numerical peak intensities, presented in counts per second, were used in the statistical evaluations.

The following XRD reflections were chosen for quantitative zeolite analysis because of their high intensities or because they did not coincide with the reflections of other phases:

SOD phases: $\mathrm{d}=3.62 \AA$ or $\mathrm{d}=3.63 \AA$

NaP1 phase: $\mathrm{d}=3.18 \AA$

Na-X phase: ca $\mathrm{d}=14.47 \AA$

CAN phases: $\mathrm{d}=3.66 \AA$ or $\mathrm{d}=3.68 \AA$

Relative zeolite contents were estimated using a four-grade scale (low, medium, high, very high).

Reflection $\mathrm{d}=5.41 \AA$ was chosen for mullite-content estimation. Because one of the strongest $\mathrm{Na}-\mathrm{X}$ phase reflections coincides with the main quartz reflection $(\mathrm{d}=3.34 \AA)$, the second most intense quartz reflection $(\mathrm{d}=4.26 \AA)$ was used. Based on an analysis of a 1:1 mullite/quartz mixture, the mullite reflection $\mathrm{d}=5.41 \AA$ was found to be half as intensive as the quartz reflection $d=4.26 \AA$. For this reason, the equation

$$
\mathrm{Mu} / \mathrm{Qtz}=2 \cdot \mathrm{Mu}\left(\mathrm{I}_{\mathrm{d}=5.41 \AA}\right) / \mathrm{Qtz}\left(\mathrm{I}_{\mathrm{d}=4.26 \AA}\right)
$$

was used to estimate the mullite/quartz ratio. 
TABLE 1

Semi-quantitative results of reactions of fly ash in hydrothermal conditions presented as intensities of chosen XRD reflections (cps)

\begin{tabular}{|c|c|c|c|c|c|c|c|c|c|}
\hline Sample & $\begin{array}{c}\mathrm{NaOH} \\
(\mathrm{M})\end{array}$ & $\begin{array}{l}\text { Time } \\
\text { (cycles) }\end{array}$ & $\begin{array}{l}\text { Temp. } \\
\left({ }^{\circ} \mathrm{C}\right)\end{array}$ & $\begin{array}{c}\text { SOD } \\
(3.63 \AA)\end{array}$ & $\begin{array}{c}\text { Na-X } \\
(14.5 \AA)\end{array}$ & $\begin{array}{c}\mathrm{NaP1} \\
(3.18 \AA ̊)\end{array}$ & $\begin{array}{c}\text { CAN } \\
(3.67 \AA)\end{array}$ & $\mathrm{Mu} / \mathrm{Qtz}$ & $\mathrm{R}$ \\
\hline $1 \mathrm{~A} 1$ & 5 & 1 & 70 & 400 & 490 & 0 & 0 & 3.00 & 1680 \\
\hline $1 \mathrm{~A} 2$ & 5 & 2 & 70 & 590 & 360 & 0 & 0 & 4.40 & 1780 \\
\hline $1 \mathrm{~A} 3$ & 5 & 3 & 70 & 730 & 680 & 0 & 0 & 3.68 & 1590 \\
\hline $1 \mathrm{~A} 4$ & 5 & 4 & 70 & 510 & 690 & 0 & 0 & 2.70 & 1550 \\
\hline 1B1 & 5 & 1 & 100 & 1280 & 100 & 0 & 0 & 10.29 & 1590 \\
\hline 1B2 & 5 & 2 & 100 & 1700 & 0 & 0 & 0 & 10.40 & 1270 \\
\hline 1B3 & 5 & 3 & 100 & 1840 & 0 & 0 & 0 & 5.00 & 1060 \\
\hline $1 \mathrm{~B} 4$ & 5 & 4 & 100 & 2070 & 0 & 0 & 0 & 9.33 & 1010 \\
\hline $1 \mathrm{C} 1$ & 5 & 1 & 150 & 900 & 0 & 0 & 930 & 2.00 & 703 \\
\hline $1 \mathrm{C} 2$ & 5 & 2 & 150 & 860 & 0 & 0 & 950 & 20.00 & 621 \\
\hline $1 \mathrm{C} 3$ & 5 & 3 & 150 & 1280 & 0 & 0 & 1000 & 2.00 & 703 \\
\hline $1 \mathrm{C} 4$ & 5 & 4 & 150 & 780 & 0 & 50 & 1090 & 2.00 & 653 \\
\hline $2 \mathrm{~A} 1$ & 3 & 1 & 70 & 0 & 100 & 0 & 0 & 2.82 & 2040 \\
\hline $2 \mathrm{~A} 2$ & 3 & 2 & 70 & 0 & 840 & 80 & 0 & 3.00 & 1640 \\
\hline $2 \mathrm{~A} 3$ & 3 & 3 & 70 & 20 & 1140 & 0 & 0 & 6.14 & 1600 \\
\hline $2 \mathrm{~A} 4$ & 3 & 4 & 70 & 40 & 1170 & 0 & 0 & 3.44 & 1350 \\
\hline $2 \mathrm{~B} 1$ & 3 & 1 & 100 & 200 & 500 & 50 & 0 & 3.26 & 1710 \\
\hline $2 \mathrm{~B} 2$ & 3 & 2 & 100 & 310 & 240 & 40 & 0 & 3.75 & 1610 \\
\hline $2 \mathrm{~B} 3$ & 3 & 3 & 100 & 860 & 260 & 120 & 0 & 13.20 & 1510 \\
\hline 2B4 & 3 & 4 & 100 & 400 & 290 & 140 & 540 & 10.57 & 1460 \\
\hline $2 \mathrm{C} 1$ & 3 & 1 & 150 & 330 & 0 & 460 & 830 & 3.00 & 880 \\
\hline $2 \mathrm{C} 2$ & 3 & 2 & 150 & 200 & 0 & 90 & 1040 & 1.00 & 840 \\
\hline $2 \mathrm{C} 3$ & 3 & 3 & 150 & 0 & 0 & 400 & 940 & 40.00 & 841 \\
\hline $2 \mathrm{C} 4$ & 3 & 4 & 150 & 0 & 0 & 330 & 1130 & 2.00 & 803 \\
\hline 3A1 & 0.5 & 1 & 70 & 0 & 0 & 0 & 0 & 2.50 & 2300 \\
\hline $3 \mathrm{~A} 2$ & 0.5 & 2 & 70 & 0 & 0 & 0 & 0 & 3.38 & 2200 \\
\hline $3 \mathrm{~A} 3$ & 0.5 & 3 & 70 & 0 & 0 & 0 & 0 & 2.80 & 2260 \\
\hline $3 \mathrm{~A} 4$ & 0.5 & 4 & 70 & 0 & 40 & 0 & 0 & 3.18 & 2110 \\
\hline 3B1 & 0.5 & 1 & 100 & 0 & 0 & 0 & 0 & 3.30 & 2360 \\
\hline $3 \mathrm{~B} 2$ & 0.5 & 2 & 100 & 0 & 0 & 0 & 0 & 3.26 & 2310 \\
\hline 3B3 & 0.5 & 3 & 100 & 0 & 0 & 0 & 0 & 3.33 & 2280 \\
\hline 3B4 & 0.5 & 4 & 100 & 100 & 0 & 0 & 0 & 3.00 & 2120 \\
\hline $3 \mathrm{C} 1$ & 0.5 & 1 & 150 & 40 & 0 & 1120 & 0 & 14.40 & 1470 \\
\hline $3 \mathrm{C} 2$ & 0.5 & 2 & 150 & 0 & 0 & 1140 & 0 & 800.00 & 1401 \\
\hline $3 \mathrm{C} 3$ & 0.5 & 3 & 150 & 0 & 0 & 1230 & 0 & 800.00 & 1401 \\
\hline $3 C 4$ & 0.5 & 4 & 150 & 0 & 0 & 1490 & 0 & 660.00 & 1161 \\
\hline
\end{tabular}

Reaction solution: $15 \mathrm{ml}$ of $\mathrm{NaOH}$ solution of various concentrations (in $\mathrm{M}$ ). Time (duration) of reaction as number of 12-hour cycles.

SOD, Na-X, NaP1, CAN - identified zeolite phases (with below - $d$ value of XRD reflection used for phase quantification).

$\mathrm{Mu} / \mathrm{Qtz}$ - mullite to quartz weight ratio. Where quantity of quartz or mullite was below detection limit, phase given a value of 1 .

$\mathrm{R}$ - relative quantity of fly-ash residual matter (aluminosilicate glass + mullite + quartz). 
TABLE 2

Semi-quantitative results of reactions of fly ash in hydrothermal conditions presented as the intensities of chosen XRD reflections (cps)

\begin{tabular}{|c|c|c|c|c|c|c|c|c|c|}
\hline Sample & $\begin{array}{l}\mathrm{NaOH} \\
(\mathrm{M})\end{array}$ & $\begin{array}{l}\text { Time } \\
\text { (cycles) }\end{array}$ & $\begin{array}{l}\text { Temp. } \\
\left({ }^{\circ} \mathrm{C}\right)\end{array}$ & $\begin{array}{c}\text { SOD } \\
(3.63 \AA)\end{array}$ & $\begin{array}{c}\mathrm{Na}-\mathrm{X} \\
(14.5 \AA)\end{array}$ & $\begin{array}{c}\mathrm{NaP1} \\
(3.18 \AA)\end{array}$ & $\begin{array}{c}\text { CAN } \\
(3.67 \AA)\end{array}$ & $\mathrm{Mu} / \mathrm{Qtz}$ & $\mathrm{R}$ \\
\hline $4 \mathrm{~A} 1$ & 5 & 1 & 70 & 0 & 690 & 0 & 0 & 3.75 & 1660 \\
\hline $4 \mathrm{~A} 2$ & 5 & 2 & 70 & 140 & 660 & 70 & 0 & 1.93 & 1420 \\
\hline $4 \mathrm{~A} 3$ & 5 & 3 & 70 & 310 & 1020 & 0 & 0 & 5.00 & 1220 \\
\hline $4 \mathrm{~A} 4$ & 5 & 4 & 70 & 350 & 820 & 0 & 0 & 2.29 & 1420 \\
\hline $4 \mathrm{~B} 1$ & 5 & 1 & 100 & 1150 & 1210 & 0 & 0 & 9.50 & 1440 \\
\hline $4 \mathrm{~B} 2$ & 5 & 2 & 100 & 2240 & 1000 & 0 & 0 & 13.20 & 1210 \\
\hline $4 \mathrm{~B} 3$ & 5 & 3 & 100 & 5030 & 370 & 0 & 0 & 4.86 & 910 \\
\hline 4B4 & 5 & 4 & 100 & 4700 & 340 & 0 & 0 & 13.00 & 1060 \\
\hline $4 \mathrm{C} 1$ & 5 & 1 & 150 & 6030 & 0 & 0 & 0 & 140.00 & 641 \\
\hline $4 \mathrm{C} 2$ & 5 & 2 & 150 & 6800 & 0 & 0 & 0 & 60.00 & 461 \\
\hline $4 \mathrm{C} 3$ & 5 & 3 & 150 & 7030 & 0 & 0 & 0 & 80.00 & 481 \\
\hline $4 \mathrm{C} 4$ & 5 & 4 & 150 & 7100 & 0 & 0 & 0 & 2.00 & 403 \\
\hline $5 \mathrm{~A} 1$ & 3 & 1 & 70 & 0 & 0 & 40 & 0 & 3.24 & 2190 \\
\hline $5 \mathrm{~A} 2$ & 3 & 2 & 70 & 30 & 620 & 230 & 0 & 2.67 & 1580 \\
\hline $5 \mathrm{~A} 3$ & 3 & 3 & 70 & 60 & 1100 & 0 & 0 & 4.93 & 1390 \\
\hline $5 \mathrm{~A} 4$ & 3 & 4 & 70 & 50 & 1270 & 0 & 0 & 2.24 & 1410 \\
\hline $5 \mathrm{~B} 1$ & 3 & 1 & 100 & 40 & 710 & 80 & 0 & 5.25 & 1800 \\
\hline $5 \mathrm{~B} 2$ & 3 & 2 & 100 & 490 & 980 & 90 & 0 & 5.07 & 1710 \\
\hline $5 \mathrm{~B} 3$ & 3 & 3 & 100 & 530 & 870 & 160 & 0 & 8.33 & 1160 \\
\hline $5 \mathrm{~B} 4$ & 3 & 4 & 100 & 600 & 390 & 170 & 0 & 11.71 & 1490 \\
\hline $5 \mathrm{C} 1$ & 3 & 1 & 150 & 1900 & 0 & 770 & 0 & 23.00 & 980 \\
\hline $5 \mathrm{C} 2$ & 3 & 2 & 150 & 4500 & 0 & 90 & 0 & 5.00 & 820 \\
\hline $5 \mathrm{C} 3$ & 3 & 3 & 150 & 2500 & 0 & 500 & 0 & 20.00 & 521 \\
\hline $5 \mathrm{C} 4$ & 3 & 4 & 150 & 3500 & 0 & 370 & 0 & 60.00 & 561 \\
\hline $6 \mathrm{~A} 1$ & 0.5 & 1 & 70 & 0 & 0 & 0 & 0 & 2.67 & 2270 \\
\hline $6 \mathrm{~A} 2$ & 0.5 & 2 & 70 & 0 & 0 & 0 & 0 & 3.57 & 2240 \\
\hline $6 \mathrm{~A} 3$ & 0.5 & 3 & 70 & 0 & 0 & 0 & 0 & 2.43 & 2290 \\
\hline $6 \mathrm{~A} 4$ & 0.5 & 4 & 70 & 0 & 0 & 0 & 0 & 3.00 & 2320 \\
\hline $6 \mathrm{~B} 1$ & 0.5 & 1 & 100 & 0 & 0 & 0 & 0 & 3.00 & 2320 \\
\hline 6B2 & 0.5 & 2 & 100 & 0 & 0 & 0 & 0 & 2.50 & 2400 \\
\hline $6 \mathrm{~B} 3$ & 0.5 & 3 & 100 & 70 & 0 & 0 & 0 & 2.29 & 2190 \\
\hline $6 \mathrm{~B} 4$ & 0.5 & 4 & 100 & 0 & 0 & 60 & 0 & 2.17 & 2260 \\
\hline $6 \mathrm{C} 1$ & 0.5 & 1 & 150 & 0 & 0 & 1570 & 0 & 6.75 & 1320 \\
\hline $6 \mathrm{C} 2$ & 0.5 & 2 & 150 & 0 & 0 & 1610 & 0 & 29.00 & 1200 \\
\hline $6 \mathrm{C} 3$ & 0.5 & 3 & 150 & 0 & 0 & 1370 & 0 & 800.00 & 1301 \\
\hline $6 \mathrm{C} 4$ & 0.5 & 4 & 150 & 0 & 0 & 1530 & 0 & 580.00 & 1081 \\
\hline
\end{tabular}

Reaction solutions: $10 \mathrm{ml}$ of $\mathrm{NaOH}$ solution of various concentrations (in $\mathrm{M}$ ) $+5 \mathrm{ml}$ of $3 \mathrm{M} \mathrm{NaCl}$ solution. Time (duration) of reaction is given as number of 12-hours cycles.

For symbols and abbreviations - see Table 1. 
To use the relative amount of total residual fly ash matter (aluminosilicate glass + + mullite + quartz) as a parameter for the degree of fly ash dissolution (R), the equation

$$
\mathrm{R}=2 \cdot \mathrm{Mu}\left(\mathrm{I}_{\mathrm{d}=5.41 \AA}\right)+\mathrm{Qtz}\left(\mathrm{I}_{\mathrm{d}=4.26 \AA}\right)+10 \cdot \mathrm{Am}\left(\mathrm{I}_{\mathrm{d}=3.50 \AA)}\right.
$$

was applied where $A m\left(I_{d=3.50 \AA}\right)$ is the intensity of the band generated by an amorphous material at $\mathrm{d}=3.50 \AA$ that no coincided with crystalline-phase reflection. The multiplication factor (10) applied was estimated from the XRD analysis of a natural glass-quartz mixture.

Morphological studies of the fly ash components and chemical analyses on a micro-scale were carried out using a field emission scanning electron microscope (HITACHI S-4700) equipped with an energy dispersive spectrometer (EDS) system VANTAGE (NORAN).

Chemical analyses were performed using pellets prepared from homogenized powders. EDS measurements involved 300 second acquisition times. The analyzed surface was ca $1 \mathrm{~mm}^{2}$. Each analysis was repeated four times from different areas and averaged.

Statistical analysis was carried out using SYSTAT software, standard methods of simple and multiple linear regression and Pearson's correlation.

Zeolite classification and structural-group nomenclature are as recommended in official publications of the International Zeolite Association (Baerlocher et al. 2001; Treacy, Higgins 2001).

\section{RESULTS}

The following zeolite phases were synthesized during the reactions (Fig. 1): sodalite (SOD), hydroxysodalite (SOD), NaP1 (GIS), Na-X (FAU) and a cancrinite/hydroxycancrinite mixture (CAN). Details of the reactions and the reaction products are given in Tables 1 and 2. Chemical analyses were performed on fly ash and on the 48-hour reaction products - the most advanced chemical transformations (Table 3).

Calcite was detected in all samples in trace amounts (not mentioned in Tables 1 and 2). This mineral is not given further consideration as it is a stable component during high $\mathrm{pH}$ treatments.

\section{SOD phases}

Sodalite and hydroxysodalite (Fig. 1) are the most abundant zeolite products of the fly ash transformations. Both sodalite and hydroxysodalite are considered together as SOD phases due to their structural similarity. Conditions of SOD crystallisation are given in Fig. 2.

Sodalite $\left(\mathrm{Cl}^{-}\right.$in the structure). High-temperature reactions with addition of $\mathrm{NaCl}$ solutions resulted in the synthesis of sodalite. Maximum sodalite crystallization occurred when highly concentrated $\mathrm{NaOH}$ solutions are used. Sodalite is the only synthe- 


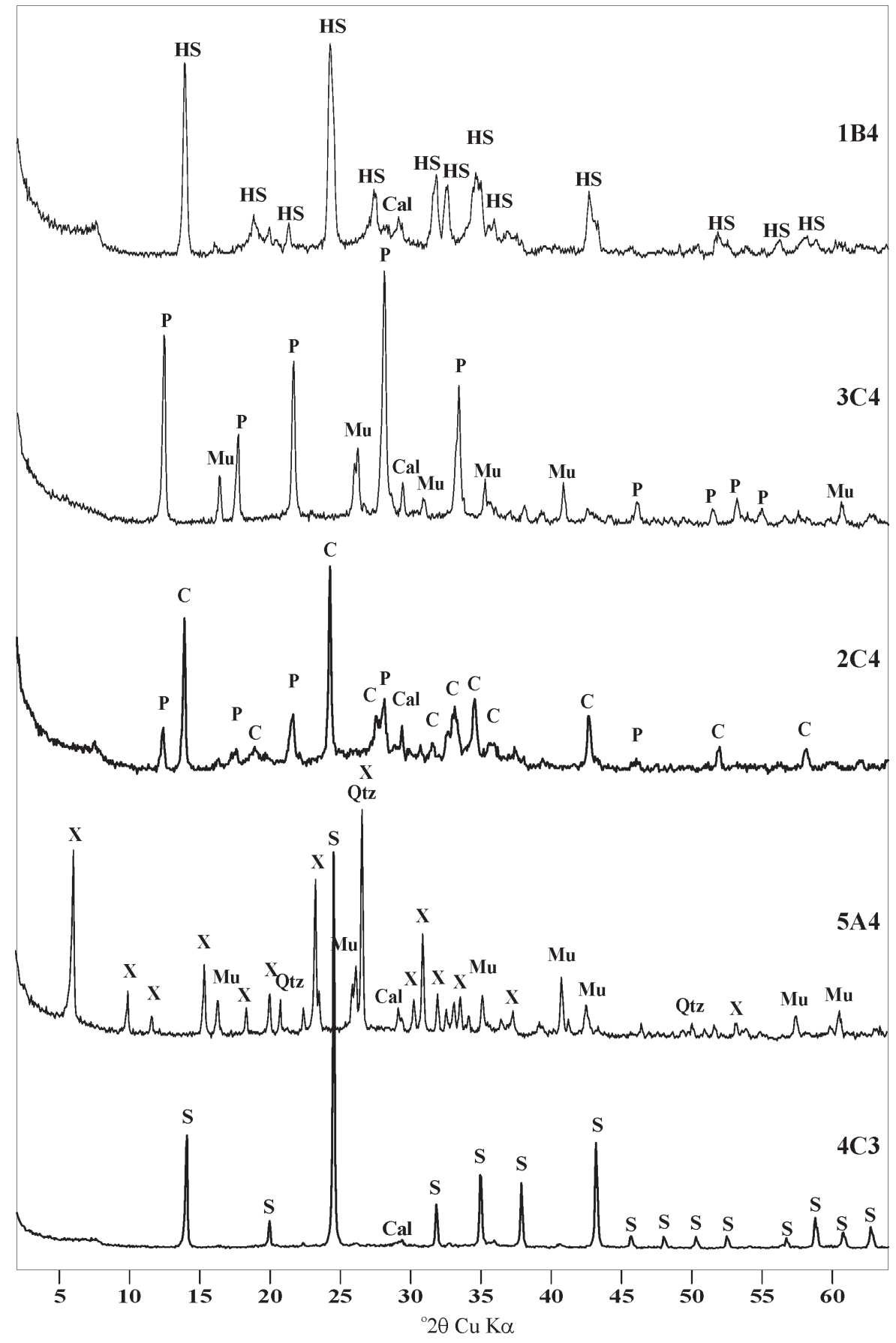

Fig. 1. XRD patterns of selected samples with high contents of sodalite (4C3), Na-X (5A4), CAN phases (2C4), NaP1 (3C4) and hydroxysodalite (1B4).

$\mathrm{Mu}$ - mullite, Qtz - quartz, Cal - calcite, S - sodalite (SOD), HS - hydroxysodalite (SOD), X - Na-X (FAU), $\mathrm{C}-\mathrm{CAN}$ phase and $\mathrm{P}-\mathrm{NaP} 1$ (GIS) 


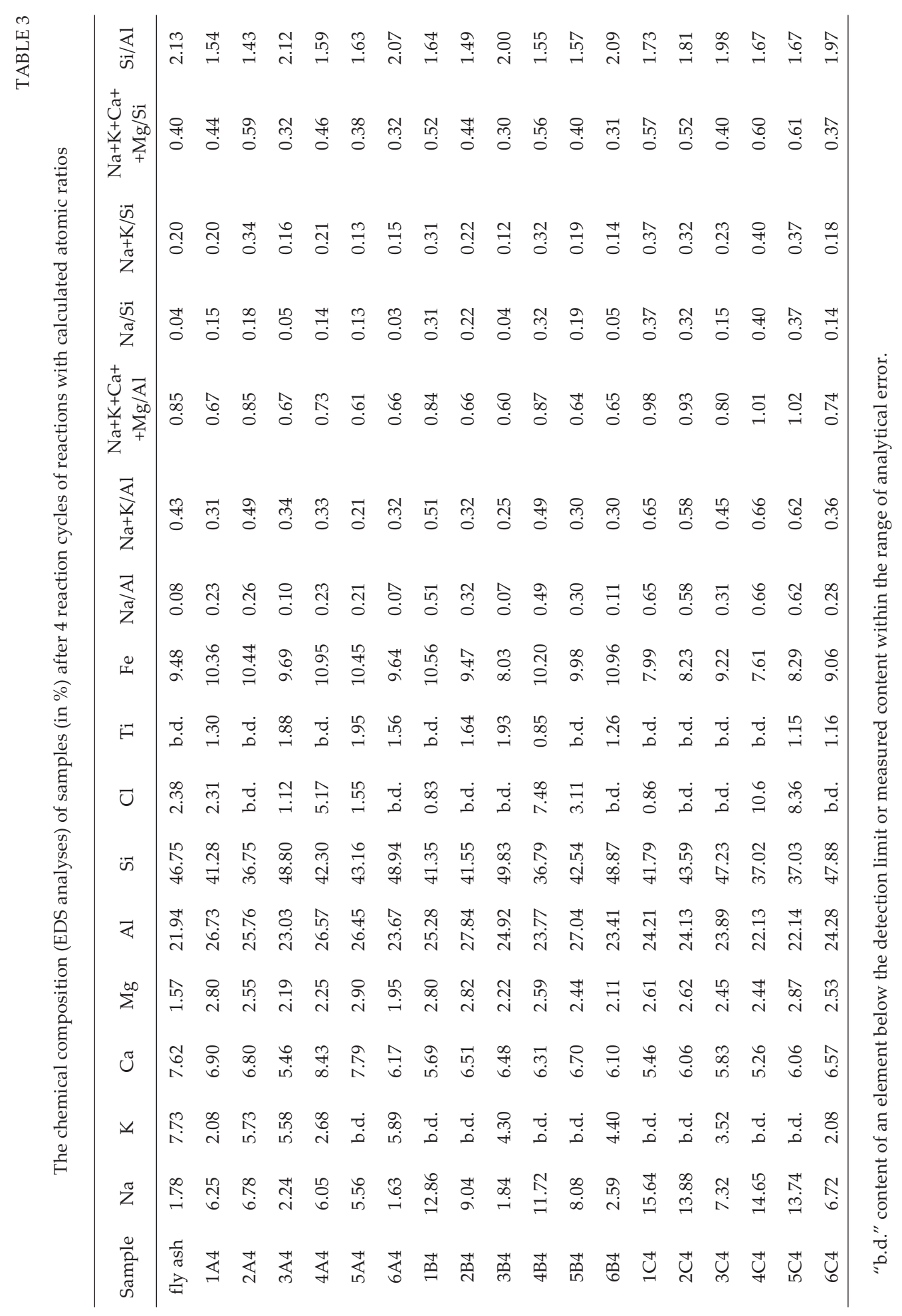




\begin{tabular}{|c|c|c|c|}
\hline \multirow{2}{*}{ concentration } & \multicolumn{3}{|c|}{ temperature } \\
\cline { 2 - 4 } & $\mathbf{7 0}^{\circ} \mathrm{C}$ & $\mathbf{1 0 0}^{\circ} \mathbf{C}$ & $\mathbf{1 5 0}^{\circ} \mathbf{C}$ \\
\hline $5 \mathrm{M} \mathrm{NaOH}$ & + & ++ & + \\
\hline$(+3 \mathrm{M} \mathrm{NaCl})$ & $*$ & $* * *$ & $* * * *$ \\
\hline $3 \mathrm{M} \mathrm{NaOH}$ & & + & \\
\hdashline$(+3 \mathrm{M} \mathbf{~ N a C l})$ & & $*$ & $* * *$ \\
\hline $0.5 \mathrm{M} \mathrm{NaOH}$ & & & \\
\hline$(+3 \mathrm{M} \mathbf{~ N a C l})$ & & & \\
\hline
\end{tabular}

a) SOD

\begin{tabular}{|c|c|c|c|}
\hline \multirow{2}{*}{ concentration } & \multicolumn{3}{|c|}{ temperature } \\
\cline { 2 - 4 } & $\mathbf{7 0}^{\circ} \mathbf{C}$ & $\mathbf{1 0 0}^{\circ} \mathbf{C}$ & $\mathbf{1 5 0}^{\circ} \mathbf{C}$ \\
\hline $\mathbf{5 M ~ N a O H}$ & & & ++ \\
\hline$(+3 \mathrm{M} \mathrm{NaCl})$ & & & \\
\hline $3 \mathrm{M} \mathrm{NaOH}$ & & & ++ \\
\hline$(+3 \mathrm{M} \mathrm{NaCl})$ & & & \\
\hline $\mathbf{0 . 5 M} \mathrm{NaOH}$ & & & \\
\hline$(+3 \mathrm{M} \mathbf{~ N a C l})$ & & & \\
\hline
\end{tabular}

\begin{tabular}{|c|c|c|c|}
\hline \multirow{2}{*}{ concentration } & \multicolumn{3}{|c|}{ temperature } \\
\cline { 2 - 4 } & $\mathbf{7 0}^{\circ} \mathrm{C}$ & $\mathbf{1 0 0}^{\circ} \mathrm{C}$ & $\mathbf{1 5 0}^{\circ} \mathrm{C}$ \\
\hline $\mathbf{5 M} \mathrm{NaOH}$ & & & \\
\hline$(+3 \mathrm{M} \mathbf{~ N a C l})$ & & & \\
\hline $3 \mathrm{M} \mathrm{NaOH}$ & & & + \\
\hline$(+3 \mathrm{M} \mathrm{NaCl})$ & & $*$ & $*$ \\
\hline $0.5 \mathrm{M} \mathrm{NaOH}$ & & & +++ \\
\hline$(+3 \mathrm{M} \mathbf{~ N a C l})$ & & & $* * *$ \\
\hline
\end{tabular}

c) $\mathrm{NaP1}$

b) CAN

\begin{tabular}{|c|c|c|c|}
\hline \multirow{2}{*}{ concentration } & \multicolumn{3}{|c|}{ temperature } \\
\hline & $7^{70^{\circ}} \mathrm{C}$ & $100^{\circ} \mathrm{C}$ & $150^{\circ} \mathrm{C}$ \\
\hline $5 \mathrm{M} \mathrm{NaOH}$ & ++ & & \\
\hline$(+3 \mathrm{M} \mathrm{NaCl})$ & $* *$ & $* *$ & \\
\hline $3 \mathrm{M} \mathrm{NaOH}$ & +++ & + & \\
\hline$(+3 \mathrm{M} \mathrm{NaCl})$ & $* * *$ & $* *$ & \\
\hline $0.5 \mathrm{M} \mathrm{NaOH}$ & & & \\
\hline$(+3 \mathrm{M} \mathrm{NaCl})$ & & & \\
\hline
\end{tabular}

d) $\mathrm{Na}-\mathrm{X}$

Fig. 2. Crystallization conditions for each zeolite phase. Time is a less important factor in most reactions. Zeolite contents in reaction products: + low; ++ medium; ++ + high; ++++ very high. Zeolite contents after reaction with addition of $3 \mathrm{M} \mathrm{NaCl}$ solution: ${ }^{*}$ low; ${ }^{* *}$ medium; ${ }^{* *}$ high; ${ }^{* * *}$ very high

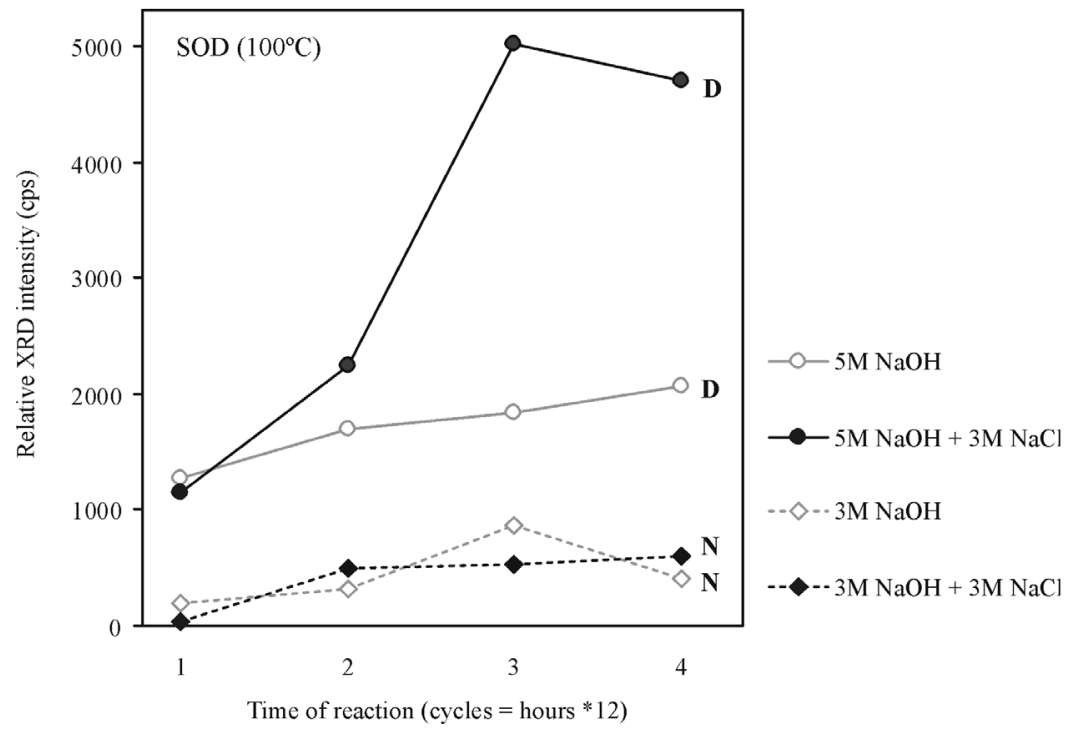

Fig. 3. SOD content determined in reaction products as XRD peak intensity at $100^{\circ} \mathrm{C}$ and at various concentrations of $\mathrm{NaOH}$ and $\mathrm{NaCl}$. SOD dominant in sample D and subordinate in $\mathrm{N}$ 
sized phase that formed a pure, monomineralic product without residual material; the fly ash material was completely dissolved during reaction.

Hydroxysodalite $\left(\mathrm{OH}^{-}\right.$in the structure) was a product of reactions without $\mathrm{NaCl}$ solutions. Its crystallization range was significantly limited in comparison with that of sodalite. Crystallization of hydroxysodalite was most effective at $100^{\circ} \mathrm{C}$ using $5 \mathrm{M}$ $\mathrm{NaOH}$ solution. Under these conditions, hydroxysodalite was the only zeolitic product with residual mullite, quartz and amorphous material.

The XRD reflections of zeolites synthesized in the presence of $\mathrm{NaCl}$ solutions (sodalite) show much higher intensities than zeolites that grew in analogous reactions without $\mathrm{NaCl}$ (hydroxysodalite). This observation applies only when SOD phases predominate among synthesized minerals (sample D in Fig. 3) and not when SOD phases are subordinate (sample $\mathrm{N}$ in Fig. 3). This effect, known from the synthesis of zeolites from pure solutions, is called the "salt effect" (Cooks, Pope 1995). In the present study, it occurred while using fly ash as the substrate material.

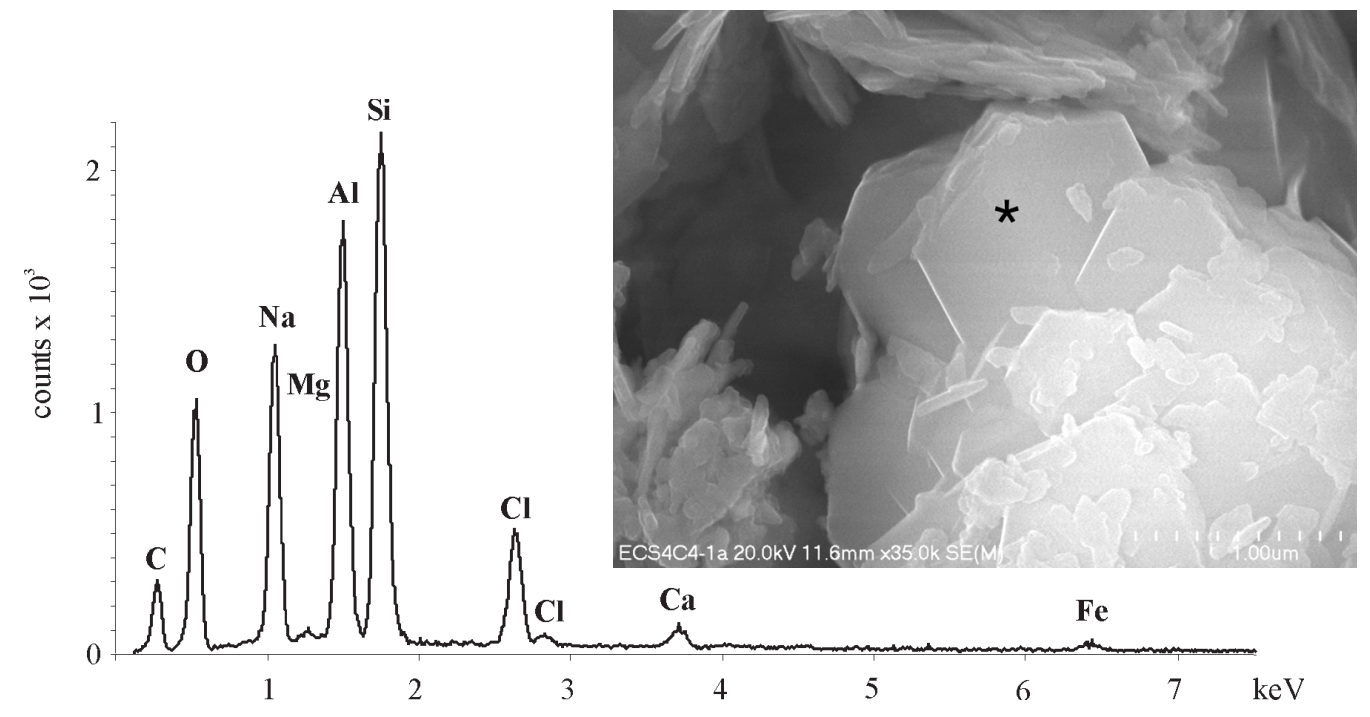

Fig. 4. SEM image (20,000X) and EDS spectrum of sodalite crystal. Sample 4C4.

Asterisk indicates location of EDS analysis spot

TABLE 4

Calculated average atomic ratios for main phases of named sample

\begin{tabular}{ccccccc}
\hline Sample & Predominant phase & $\mathrm{Na}+\mathrm{K} / \mathrm{Si}$ & $\begin{array}{c}\mathrm{Na}+\mathrm{K}+\mathrm{Ca}+ \\
+\mathrm{Mg} / \mathrm{Si}\end{array}$ & $\mathrm{Na}+\mathrm{K} / \mathrm{Al}$ & $\begin{array}{c}\mathrm{Na}+\mathrm{K}+\mathrm{Ca}+ \\
+\mathrm{Mg} / \mathrm{Al}\end{array}$ & $\mathrm{Si} / \mathrm{Al}$ \\
\hline $2 \mathrm{C} 4$ & hydroxycancrinite & 0.67 & 0.77 & 0.85 & 0.98 & 1.27 \\
$3 \mathrm{C} 4$ & $\mathrm{NaP1}$ & 0.28 & 0.47 & 0.44 & 0.75 & 1.58 \\
$4 \mathrm{C} 4$ & sodalite & 0.97 & 1.06 & 1.17 & 1.29 & 1.21 \\
$5 \mathrm{~A} 4$ & $\mathrm{Na}-\mathrm{X}$ & 0.38 & 0.59 & 0.42 & 0.64 & 1.08 \\
$6 \mathrm{C} 4$ & $\mathrm{NaP1}$ & 0.28 & 0.37 & 0.49 & 0.64 & 1.74 \\
\hline
\end{tabular}


The content of $\mathrm{Cl}$ atoms in sodalite (Fig. 4) confirms that incorporation of $\mathrm{Cl}^{-}$took place during reactions involving added $\mathrm{NaCl}$ solution. $\mathrm{Cl}$ is also abundant in the bulk sample (Table 3). Atomic ratios for the sodalite are given in Table 4.

\section{CAN phases (cancrinite/hydroxycancrinite mixture)}

Crystallization of CAN phases (Fig. 5) took place only over a narrow range of reaction conditions (Fig. 2). The absence of $\mathrm{Cl}^{-}$in the reaction mixture is a crucial condition for CAN synthesis ( $\mathrm{Cl}^{-}$is not accepted in CAN structure) as the addition of $\mathrm{NaCl}$ solution causes crystallization of SOD phases under the same conditions (Armstrong, Dann 2000). CAN phases predominated among products of reactions at the highest temperatures $\left(150^{\circ} \mathrm{C}\right.$ ) and using $3 \mathrm{M} \mathrm{NaOH}$ solution (trace amounts of $\mathrm{NaP} 1$ and SOD phases also occurred). Higher concentrations of $\mathrm{NaOH}$ led to co-precipitation of CAN and SOD. A characteristic feature of samples containing CAN was the lack of crystalline residual phases though the raised background line of their XRD patterns indicated the presence of an amorphous phase (Tables 1 and 2).

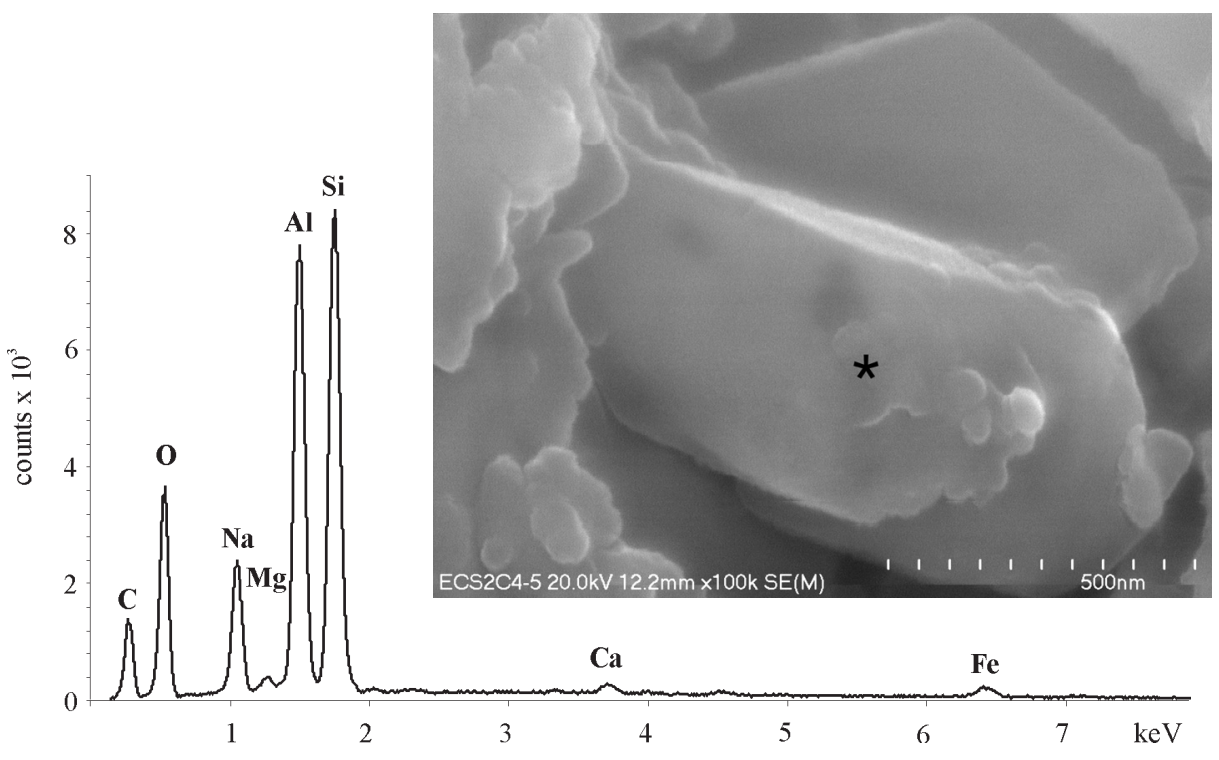

Fig. 5. SEM image (100,000X) and EDS spectrum of hydroxycancrinite crystal. Sample 2C4. Asterisk indicates location of EDS analysis spot

NaP1 (GIS) phases

Crystallization of NaP1 phases took place during reactions at the highest temperatures $\left(150^{\circ} \mathrm{C}\right)$ and the lowest $\mathrm{NaOH}$ concentrations. The presence of $\mathrm{Cl}^{-}$was not critical (Fig. 2). EDS data indicate that $\mathrm{Cl}$ is absent in the structure of the NaP1 (Fig. 6) synthesized with $\mathrm{NaCl}$ added. In samples with high NaPI contents, only mullite and glass were residual phases and quartz was absent or present only in trace amounts. 


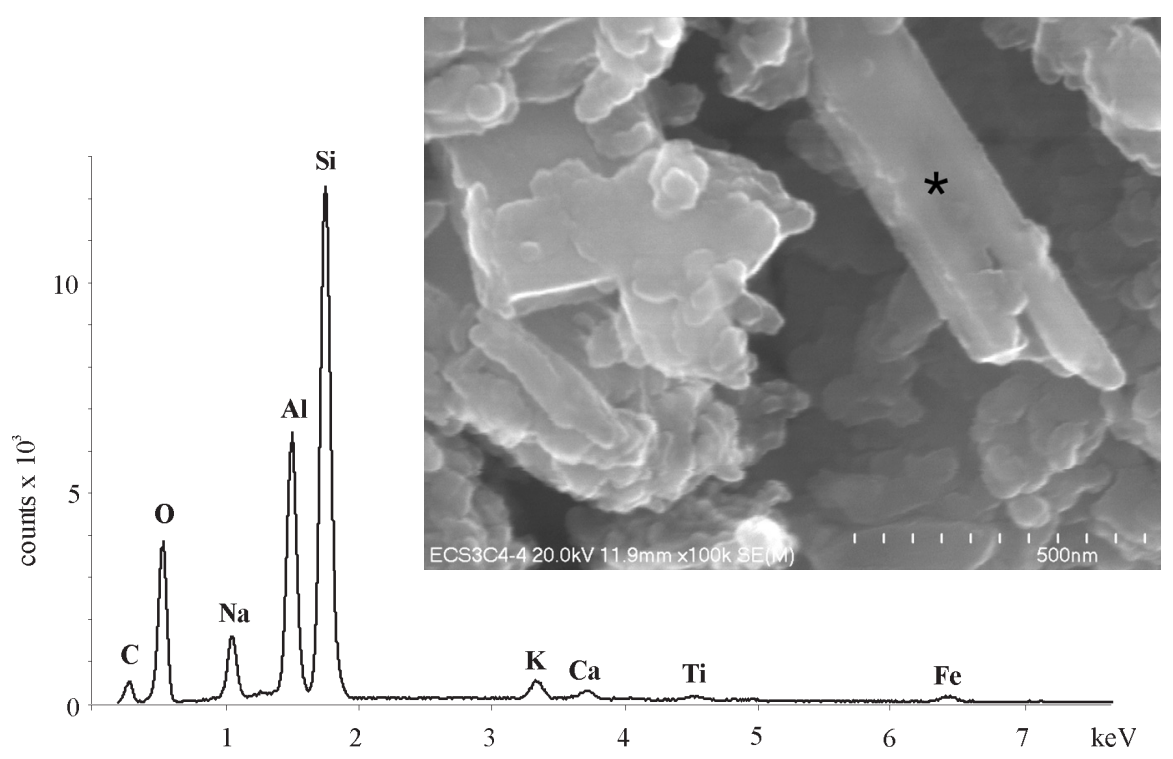

Fig. 6. SEM image (100,000X) and EDS spectrum of NaP1 crystal. Sample 3C4. Asterisk indicates location of EDS analysis spot

Na-X (FAU) phases

$\mathrm{Na}-\mathrm{X}$ zeolite occurred among the products of reactions at low-medium temperatures $\left(70\right.$ and $100^{\circ} \mathrm{C}$; Figs 2, 7). The highest $\mathrm{Na}-\mathrm{X}$ contents resulted from the reactions at $70^{\circ} \mathrm{C}$ with $3 \mathrm{M} \mathrm{NaOH}$ solutions. The positive influence of added $\mathrm{NaCl}$ on the rate of

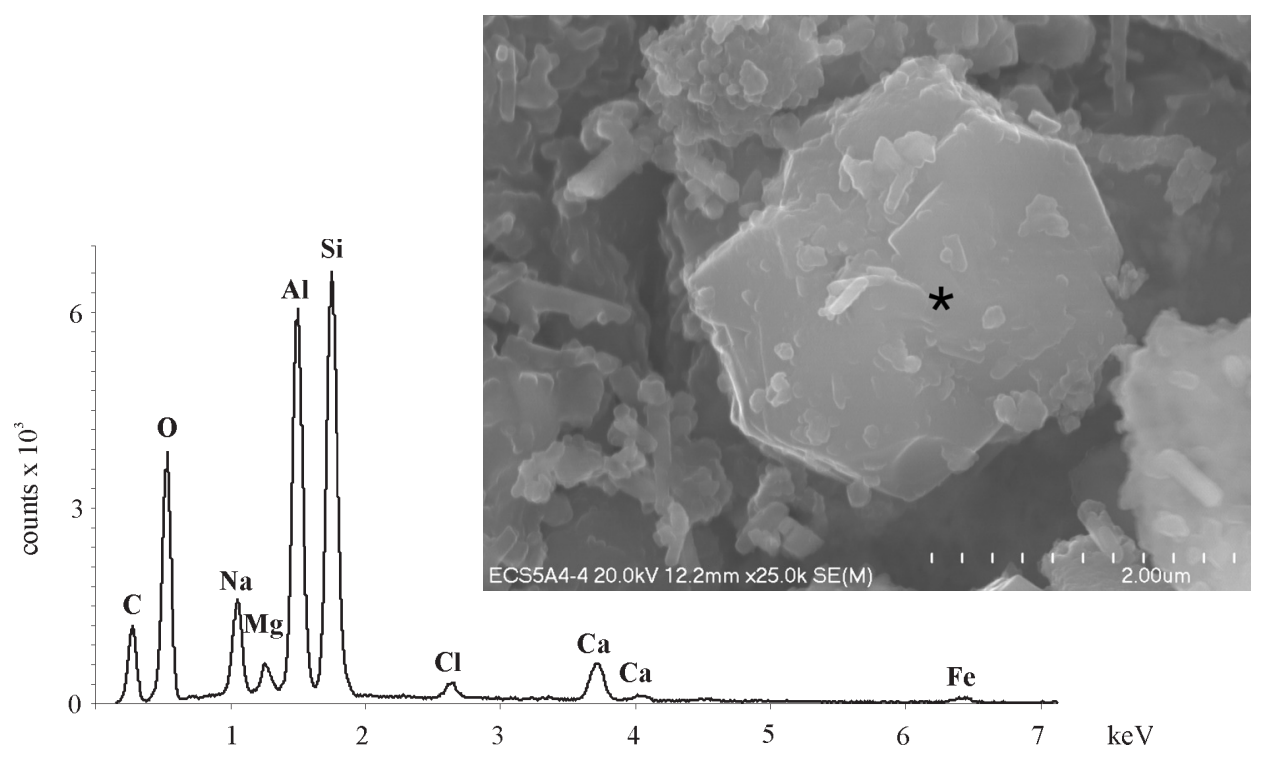

Fig. 7. SEM image (25,000X) and EDS spectrum of Na-X crystal - documenting characteristic low Si/Al. Sample 5A4. Asterisk indicates location of EDS analysis spot 
$\mathrm{Na}-\mathrm{X}$ crystallization was evident at medium temperatures $\left(100^{\circ} \mathrm{C}\right)$. The "salt effect" (Cooks, Pope 1995) was probably indicated for the X type phases. Samples dominated by $\mathrm{Na}-\mathrm{X}$ showed high contents of residual mullite and quartz, and minor glass.

\section{DISCUSSION}

Statistical evaluations of mineralogical and reaction parameters are based on the data shown in Table 1 and 2 . The contents of each zeolite phase, the mullite/quartz ratio $(\mathrm{Mu} / \mathrm{Qtz})$ and the contents of residual matter $(\mathrm{R})$ in all samples were correlated with various reaction parameters using linear regressions of individual data (Table 5). As simultaneous relations of reaction parameters were not considered, the evaluations mentioned above had to be recalculated and confirmed by multiple linear regression modeling that considered all reaction parameters but indicated probabilities only (p; Table 6). Correlations between the contents of each zeolite, Mu/Qtz and R were also evaluated (Table 7). In addition, statistical evaluation of the reaction parameters (Table 8), as well as Mu/Qtz and $\mathrm{R}$ (Table 9) versus atomic ratios in samples were carried out (see Table 3).

TABLE 5

Simple linear regression models and Pearson correlation coefficients calculated for the reaction parameters (reagents concentration, time and temperature) and mineral components as continuous (not categorized) data

\begin{tabular}{|c|c|c|c|c|c|c|c|}
\hline \multicolumn{2}{|c|}{ Parameter } & SOD & $\mathrm{Na}-\mathrm{X}$ & $\mathrm{NaP1}$ & CAN & $\mathrm{Mu} / \mathrm{Qtz}$ & $\mathrm{R}$ \\
\hline \multirow{3}{*}{$\begin{array}{c}\mathrm{NaOH} \\
(\mathrm{M})\end{array}$} & $\mathrm{r}$ & 0.5030 & 0.3830 & 0.4290 & 0.2230 & 0.3180 & 0.6060 \\
\hline & $\mathrm{p}$ & 0.0000 & 0.0010 & 0.0000 & 0.0590 & 0.0070 & 0.0000 \\
\hline & $\mathrm{b}$ & 487.2130 & 81.6330 & -102.3980 & 38.3130 & -31.9220 & -187.8730 \\
\hline \multirow{3}{*}{$\begin{array}{c}\mathrm{NaCl}^{*} \\
(\mathrm{M})\end{array}$} & $\mathrm{r}$ & 0.3090 & 0.1820 & 0.0620 & 0.3710 & 0.0410 & 0.0670 \\
\hline & $\mathrm{p}$ & 0.0080 & 0.1260 & 0.6030 & 0.0010 & 0.7340 & 0.5780 \\
\hline & b & & & & & & \\
\hline \multirow{3}{*}{$\begin{array}{l}\text { Time } \\
\text { (cycles) }\end{array}$} & $\mathrm{r}$ & 0.0910 & 0.0690 & 0.0070 & 0.0580 & 0.1420 & 0.1890 \\
\hline & $\mathrm{p}$ & 0.4460 & 0.5640 & 0.9540 & 0.6280 & 0.2350 & 0.1110 \\
\hline & $\mathrm{b}$ & 145.5000 & 24.2780 & 2.7220 & 16.3890 & 23.4700 & -96.6720 \\
\hline \multirow{3}{*}{$\mathrm{T}\left({ }^{\circ} \mathrm{C}\right)$} & $\mathrm{r}$ & 0.3820 & 0.5110 & 0.5660 & 0.4520 & 0.4000 & 0.6960 \\
\hline & $\mathrm{p}$ & 0.0010 & 0.0000 & 0.0000 & 0.0000 & 0.0000 & 0.0000 \\
\hline & b & 20.6630 & -6.0850 & 7.5310 & 4.3260 & 2.2450 & -12.0270 \\
\hline
\end{tabular}

$\mathrm{r}$ - Pearson correlation coefficient; $\mathrm{p}$ - significance of correlation (probability); $\mathrm{b}$ - slope of simple regression line; * 2 categories only for $\mathrm{NaCl}$ content; coefficient not calculated; $\mathrm{NaOH}(\mathrm{M}), \mathrm{NaCl}(\mathrm{M})$ solutions used in reactions; $\mathrm{T}$ - temperature; symbols $\mathrm{Mu} / \mathrm{Qtz}$ and $\mathrm{R}$ - see Table 1. 
TABLE 6

Significance of correlation (p) calculated on the basis of multiple linear regression (continuous data)

\begin{tabular}{ccccccc}
\hline $\mathrm{P}$ & $\mathrm{SOD}$ & $\mathrm{Na}-\mathrm{X}$ & $\mathrm{NaP} 1$ & $\mathrm{CAN}$ & $\mathrm{Mu} / \mathrm{Qtz}$ & $\mathrm{R}$ \\
\hline $\mathrm{NaOH}(\mathrm{M})$ & 0.0000 & 0.0000 & 0.0000 & 0.0220 & 0.0030 & 0.0000 \\
$\mathrm{NaCl}(\mathrm{M})$ & 0.0010 & 0.0490 & 0.4700 & 0.0000 & 0.6950 & 0.1020 \\
$\mathrm{time}(\mathrm{cycles})$ & 0.2930 & 0.4500 & 0.9360 & 0.5440 & 0.1750 & 0.0000 \\
$\mathrm{~T}\left({ }^{\circ} \mathrm{C}\right)$ & 0.0000 & 0.0000 & 0.0000 & 0.0000 & 0.0000 & 0.0000 \\
\hline
\end{tabular}

Symbols Mu/Qtz and R - see Table 1.

TABLE 7

Parameters of the simple linear regression models and Pearson correlation coefficient (continuous data)

\begin{tabular}{|c|c|c|c|c|c|c|}
\hline \multicolumn{2}{|c|}{ Parameter } & SOD & $\mathrm{NaX}$ & $\mathrm{NaP1}$ & CAN & $\mathrm{Mu} / \mathrm{Qtz}$ \\
\hline \multirow{3}{*}{$\mathrm{Mu} / \mathrm{Qtz}$} & $\mathrm{r}$ & 0.0800 & 0.0270 & 0.4770 & 0.1050 & \\
\hline & $\mathrm{p}$ & 0.5050 & 0.0900 & 0.0000 & 0.3810 & \\
\hline & b & -0.7700 & -0.4270 & 1.6530 & -0.1790 & \\
\hline \multirow{3}{*}{$\mathrm{R}$} & $\mathrm{r}$ & 0.6150 & 0.0160 & 0.2160 & 0.4290 & 0.1320 \\
\hline & $\mathrm{p}$ & 0.0000 & 0.8970 & 0.0690 & 0.0000 & 0.2690 \\
\hline & b & -1.9240 & 0.0110 & -0.1660 & -0.2380 & -0.0430 \\
\hline
\end{tabular}

Symbols: $\mathrm{r}, \mathrm{p}, \mathrm{b}$ - see Table 5; Mu/Qtz and $\mathrm{R}$ - see Table 1 .

TABLE 8

Significance of correlation ( $\mathrm{p}$ ) calculated on the basis of multiple linear regressions

\begin{tabular}{cccccccc}
\hline $\mathrm{p}$ & $\mathrm{Na} / \mathrm{Al}$ & $\mathrm{Na}+\mathrm{K} / \mathrm{Al}$ & $\begin{array}{c}\mathrm{Na}+\mathrm{K}+\mathrm{Ca}+ \\
+\mathrm{Mg} / \mathrm{Al}\end{array}$ & $\mathrm{Na} / \mathrm{Si}$ & $\mathrm{Na}+\mathrm{K} / \mathrm{Si}$ & $\begin{array}{c}\mathrm{Na}+\mathrm{K}+\mathrm{Ca}+ \\
+\mathrm{Mg} / \mathrm{Si}\end{array}$ & $\mathrm{Si} / \mathrm{Al}$ \\
\hline $\begin{array}{c}\mathrm{NaOH} \\
(\mathrm{M})\end{array}$ & $\begin{array}{c}0.00000 \\
(+)\end{array}$ & $\begin{array}{c}0.00800 \\
(+)\end{array}$ & $\begin{array}{c}0.00547 \\
(+)\end{array}$ & $\begin{array}{c}0.00000 \\
(+)\end{array}$ & $\begin{array}{c}0.00081 \\
(+)\end{array}$ & $\begin{array}{c}0.00015 \\
(+)\end{array}$ & $\begin{array}{c}0.00012 \\
(-)\end{array}$ \\
$\begin{array}{c}\mathrm{NaCl} \\
(\mathrm{M})^{*}\end{array}$ & 0.83601 & 0.43094 & 0.83503 & 0.91361 & 0.44845 & 0.79147 & 0.88362 \\
$\mathrm{~T}\left({ }^{\circ} \mathrm{C}\right)$ & $\begin{array}{c}0.00000 \\
(+)\end{array}$ & $\begin{array}{c}0.00040 \\
(+)\end{array}$ & $\begin{array}{c}0.00050 \\
(+)\end{array}$ & $\begin{array}{c}0.00001 \\
(+)\end{array}$ & $\begin{array}{c}0.00253 \\
(+)\end{array}$ & $0.01566(+)$ & 0.34175 \\
\hline
\end{tabular}

Continuous data, ${ }^{*} \mathrm{NaCl}$ - categorized data. Direction of correlation in brackets (+ positive, - negative) for statistically significant correlations. 
TABLE 9

Parameters of the simple linear regression models and Pearson correlation coefficient (continuous data)

\begin{tabular}{ccccccccc}
\hline Parameter & $\mathrm{Na} / \mathrm{Al}$ & $\mathrm{Na}+\mathrm{K} / \mathrm{Al}$ & $\begin{array}{c}\mathrm{Na}+\mathrm{K}+\mathrm{Ca}+ \\
+\mathrm{Mg} / \mathrm{Al}\end{array}$ & $\mathrm{Na} / \mathrm{Si}$ & $\mathrm{Na}+\mathrm{K} / \mathrm{Si}$ & $\begin{array}{c}\mathrm{Na}+\mathrm{K}+\mathrm{Ca}+ \\
+\mathrm{Mg} / \mathrm{Si}\end{array}$ & $\mathrm{Si} / \mathrm{Al}$ \\
\hline $\mathrm{Mu} / \mathrm{Qtz}$ & $\mathrm{b}$ & -0.00005 & 0.00001 & 0.00001 & -0.00007 & -0.00005 & -0.00010 & 0.00039 \\
& $\mathrm{p}$ & 0.8530 & 0.9660 & 0.9430 & 0.6310 & 0.6590 & 0.4830 & 0.1610 \\
\hline & $\mathrm{r}$ & 0.93849 & 0.82114 & 0.85852 & 0.92629 & 0.84770 & 0.85351 & 0.49353 \\
$\mathrm{R}$ & $\mathrm{b}$ & -0.00033 & -0.00020 & -0.00021 & -0.00020 & -0.00014 & -0.00016 & 0.00019 \\
& $\mathrm{p}$ & 0.0470 & 0.0110 & 0.0180 & 0.1220 & 0.1120 & 0.1770 & 0.3450 \\
\hline
\end{tabular}

Symbols: r, p, b - see Table 5; Mu/Qtz and R - see Table 1.

Accepting that the limit of significance for correlation between data series is $p \approx 0.04$, as suggested for natural sciences by Łomnicki (2000), clear correlations of zeolite-phase content with $\mathrm{NaOH}$ concentration and with reaction temperature are evident (Tables 5 and 6). Reaction time is a less important factor than others ( $p>>0.04$ ), especially in qualitative analyses of crystallized phases.

Time as a reaction parameter is negligible in generalized plots of crystallization conditions ("crystallization fields") though it is more significant in borderline zones (Fig. 8). An increase of reaction time can move the boundary of a crystallization field into that of another (usually higher-temperature) phase and can change the quantitative ratios of zeolite phases in a mixture. Most reactions show an increase in zeolite content with increasing time of reaction - especially in the case of $\mathrm{Na}-\mathrm{X}$.

The crystallization of the predominant zeolite phases depends, though not linearly, on the temperature of reaction and the concentration of the $\mathrm{NaOH}$ solution. Only the CAN phase content is correlated (negatively) with $\mathrm{NaCl}$. The SOD phases attain their maximum contents when $\mathrm{NaCl}$ is present. The influence of the $\mathrm{Cl}^{-}$on $\mathrm{Na}-\mathrm{X}$ and $\mathrm{NaP1}$ crystallization is negligible.

Synthesized zeolite phases commonly occur among the products of hydrothermal transformation of fly ash under alkaline conditions. The crystallization fields of the phases and the trends of mineral transformation determined here compare with those found by other authors (e.g. Querol et al. 1997; Chang, Shih 1998).

Residual matter $(\mathrm{R})$ clearly decreases with rising reaction temperatures and higher $\mathrm{NaOH}$ concentrations. There is also a weak correlation with increasing reaction time.

Differences between residual mullite and quartz contents correlate only with temperature and $\mathrm{NaOH}$ concentration. Increasing temperature promotes dissolution of quartz over that of mullite. NaP1 and SOD contents increase as residual matter decreases. That $\mathrm{NaP} 1$ contents correlate positively with accelerated dissolution of quartz relative to that of mullite indicates that $\mathrm{NaP} 1$ crystallisation took place from a solution 

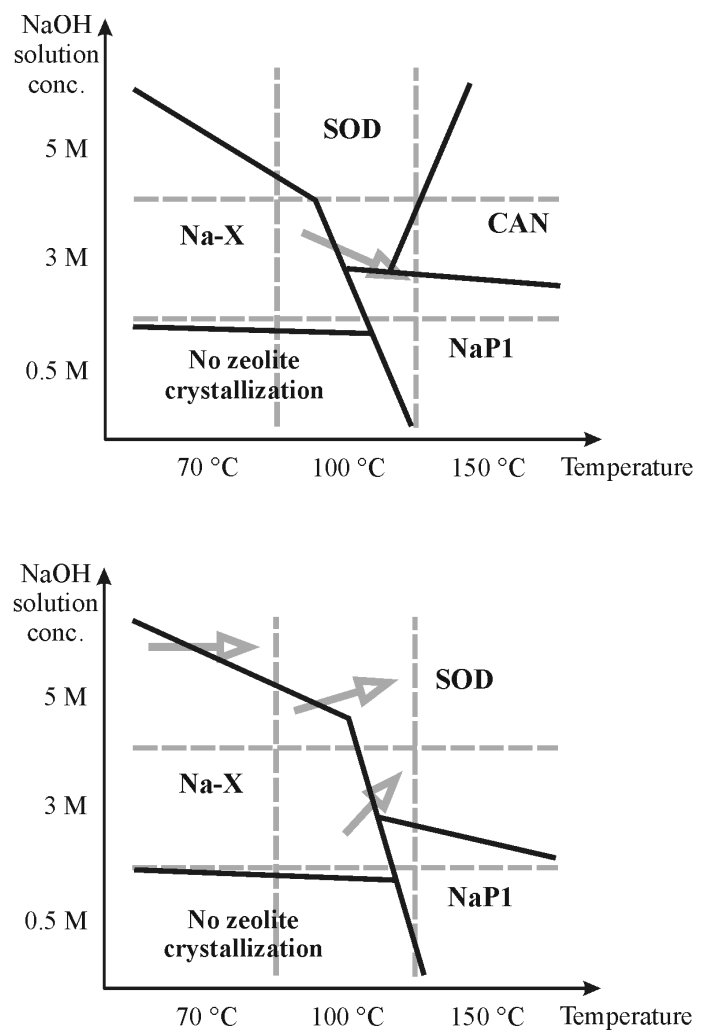

Fig. 8. Plots of crystallization fields based on concentration of $\mathrm{NaOH}$ solution and reaction temperature of reaction without (upper) or with (lower) an addition of $\mathrm{NaCl}$ solution. Gray arrows indicate directions of changes with increasing reaction times. Vertical and horizontal lines indicate groups of samples prepared under the reaction conditions labeled at axes

of higher Si content than required by other zeolites. This is consistent with the fact that the $\mathrm{Si} / \mathrm{Al}$ molar ratio of $\mathrm{NaP1}$ is the highest among all crystallized zeolites. Similar results were presented by Hollman et al. (1999) who synthesized various zeolites at $90^{\circ} \mathrm{C}$ by reacting fly ash with $2 \mathrm{M} \mathrm{NaOH}$ solution before modifying the solution $\mathrm{Si} / \mathrm{Al}$ ratio. The Na-A (+ SOD) phase crystallized in a solution with $\mathrm{Si} / \mathrm{Al}=1.2, \mathrm{Na}-\mathrm{X}$ in a solution with $\mathrm{Si} / \mathrm{Al}=1.8$ and $\mathrm{NaP} 1$ commenced its growth in solution with $\mathrm{Si} / \mathrm{Al}=2.0$.

Increased reaction times can cause the crystallization of both SOD phases at the expense of $\mathrm{NaP} 1$ under reaction conditions located in the border zones of crystallization fields - as also found by Kolay and Singh (2002). Similar border-zone changes take place with the use of more concentrated $\mathrm{NaOH}$ solutions (Querol et al. 1997; Derkowski 2002a). Many papers report hydroxysodalite as a product of reaction of F-class fly ash with highly-concentrated $\mathrm{NaOH}$ solutions $(\geq 3 \mathrm{M})$ at ca $100^{\circ} \mathrm{C}$ (e.g., Poole et al. 2000).

The chemical compositions of samples after 48 hours ( 4 cycles) reacting are similar to each other in some respects (Table 3 ). The Fe content is nearly constant in all - probably because Fe occurs in the stable (hydro-) oxide form. $\mathrm{Cl}^{-}$contents are significantly higher in materials reacted in solutions with $\mathrm{NaCl}$. $\mathrm{Ca}$ and $\mathrm{Mg}$ contents do not significantly 
differ. That alkali/Al and alkali/Si show similar negative correlations with $\mathrm{R}$ (Table 9) is a result of increasing contents of alkali-rich zeolite phases at the expense of low-alkali substrates. This explains the obvious positive correlations of these ratios with $\mathrm{Na}$ (as $\mathrm{NaOH}$ ) contents in reaction solutions and with temperature (Table 8).

Whole-sample $\mathrm{Si} / \mathrm{Al}$ values correlate negatively only with the concentrations of $\mathrm{NaOH}$ solutions. They neither correlate with temperature nor with $\mathrm{Mu} / \mathrm{Qtz}$. Irrespective of reaction conditions, all samples show a decrease in $\mathrm{Si} / \mathrm{Al}$ with respect to the raw fly ash (Table 3) although any quantitative relationship with $\mathrm{R}$ is not clear (Table 9). All synthesized zeolite phases have $\mathrm{Si} / \mathrm{Al}$ lower than substrate values (Table 4). The $\mathrm{Si} / \mathrm{Al}$ of each sample is a mean of $\mathrm{Si} / \mathrm{Al}$ in new phases and in residual material due to (a) crystallization of new zeolite phases with $\mathrm{Si} / \mathrm{Al}$ lower than that of the starting material and/or (b) selective dissolution of ash components leading to relative enrichment of the reaction solution in $\mathrm{Si}$.

It is clear that all zeolite phases crystallized from solutions of higher $\mathrm{Si} / \mathrm{Al}$ than determined in their structure. Thus, Al ions existing in the reaction solution were preferentially used in the crystallization of new phases, resulting in an excess of $\mathrm{Si}$ in solution. This conclusion is consistent with the rules governing zeolite crystallization (Breck 1974) and with other results of other experiments on the synthesis of zeolites from fly ash (e.g., Shih, Chang 1996; Hollman et al. 1999; Murayama et al. 2002). Increasing $\mathrm{OH}^{-}$in reaction solutions reduces the $\mathrm{Si} / \mathrm{Al}$ in solution and in crystallizing phases (Breck 1974; Lechert 1996; Lindner, Lechert 1996). The Si/Al of zeolite phases (Table 4), when superimposed on the crystallization field pattern, show a characteristic increase with increasing temperatures and with lower-concentrations of $\mathrm{NaOH}$ solutions (Fig. 9). It may be concluded that higher absolute contents of $\mathrm{NaOH}$ in solution can lower $\mathrm{Si} / \mathrm{Al}$ in the solution and in the crystallized phases. Higher $\mathrm{NaOH}$ contents also accellerate dissolution of ash material. In this case, $\mathrm{Si} / \mathrm{Al}$ in samples after reaction with solutions of low $\mathrm{OH}^{-}$concentration should be higher than after reaction with solutions of high $\mathrm{OH}^{-}$ concentration. The linear regression between sample Si/Al and absolute contents of $\mathrm{OH}^{-}$ (in milimole) in reaction solutions shows $r=0.75676, p=0.00028$ and $b=-0.00678$ (for symbols - see Table 5). This confirms that our suggestion is correct.

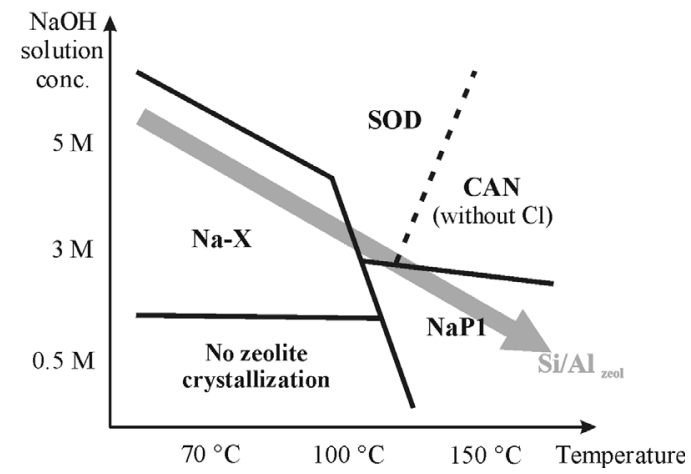

Fig. 9. Crystallization fields (generalized) of zeolite phases synthesized during hydrothermal transformations of the F-class fly ash under high-alkali conditions.

The gray arrow represents an increase in zeolite $\mathrm{Si} / \mathrm{Al}$ 
Assuming that $\mathrm{Mu} / \mathrm{Qtz}$ is an indicator of the intensity of Si and Al leaching from the raw material, relative increases in residual $\mathrm{Al}$ contents and in solution Si contents are to be expected at higher temperatures.

The zeolite phases that crystallize depend on the $\mathrm{OH}^{-}$and $\mathrm{Cl}^{-}$contents of the reaction solutions. The influence of $\mathrm{Cl}^{-}$is best seen in the products of reactions at the highest temperatures $\left(150^{\circ} \mathrm{C}\right)$. A simple scheme based on the experimental results is proposed (Fig. 10).

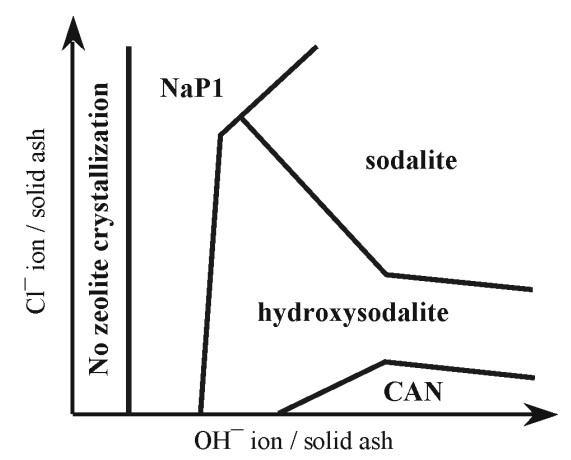

Fig. 10. Crystallization fields (generalized) of zeolite phases based on the $\mathrm{OH}^{-}$and $\mathrm{Cl}^{-}$ contents in reaction solutions related to the mass of fly ash

During fly-ash dissolution, the main sources of the $\mathrm{Si}$ and $\mathrm{Al}$ in solution are aluminosilicate glass and mullite. Quartz is probably the minor Si source because of its low content in ash. The absolute amount of Si in solution leached from aluminosilicate glass is several times greater than that derived from quartz. Some samples (e.g., 3C4) show high contents of an amorphous phase whereas quartz XRD reflection intensities were strongly reduced. $\mathrm{Si} / \mathrm{Al}$ in reaction solutions is not controlled by the dissolution of ash components according to their dissolution rates but on the selective leaching from various ash phases. For amorphous glasses, a complicated, poly-sequential process that proceeds under far-from-equilibrium conditions is involved (Yan, Neretnieks 1995; Oelkers 2001). The dissolution of glassy ash components correlates strongly with $\mathrm{NaOH}$ concentration (increasing $\mathrm{pH}$ ) and temperature. This has been confirmed by experiments on volcanic glass dissolution (Fiore et al. 2001; Derkowski 2002b).

Increasing $\mathrm{Si}$ and $\mathrm{Al}$ in reaction solutions coincides with the dissolution of ash components and thus depends on $\mathrm{OH}^{-}$activity and temperature. In general, the following dissolution steps in the advancing reaction as temperature and $\mathrm{OH}^{-}$activity increases and time passes may be defined:

1. Dissolution of aluminosilicate glass ( $\mathrm{Si} / \mathrm{Al} \sim 1.8-2.0$ ).

2. Dissolution of quartz.

3. Dissolution of mullite.

A graphic interpretation of associated changes in $\mathrm{Si}$ and $\mathrm{Al}$ concentrations, and ratios in solution, is given in Fig. 11.

The processes described can proceed simultaneously, but with differing efficiencies, depending on reaction conditions. With increasing $\mathrm{pH}$, the rate of $\mathrm{Al}$ leaching increases, 


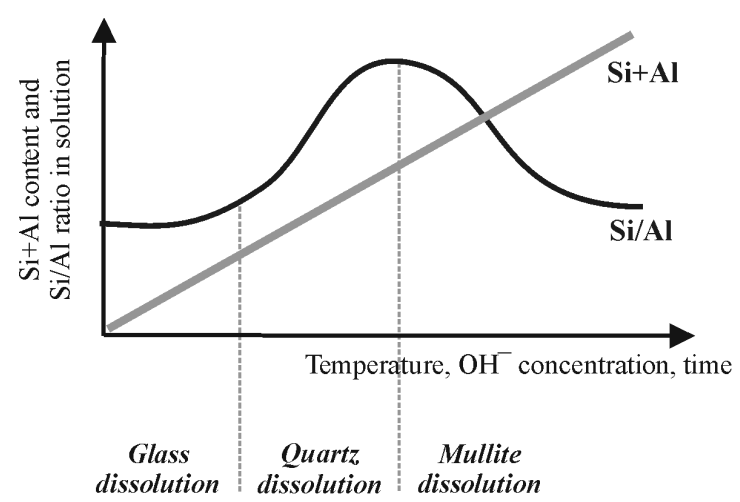

Fig. 11. Changes in $\mathrm{Si}$ and $\mathrm{Al}$ contents (generalized) in reaction solution related to sequential dissolution of fly ash components.

Changes of $\mathrm{Si}$ and $\mathrm{Al}$ due to the crystallization of new phases not been taken into account

as does the leaching of Si but more slowly (Breck 1974; Lindner, Lechert 1996); this may correlate with higher rates of mullite dissolution. Lower $\mathrm{pH}$ conditions preferentially promote the leaching of $\mathrm{Si}$ and, thus, a significant reduction in quartz content. Some reports suggest that quartz can dissolve faster than aluminosilicate glass in specific cases (Querol et al. 1995, 1997b; Murayama et al. 2002). In highly alkaline conditions,

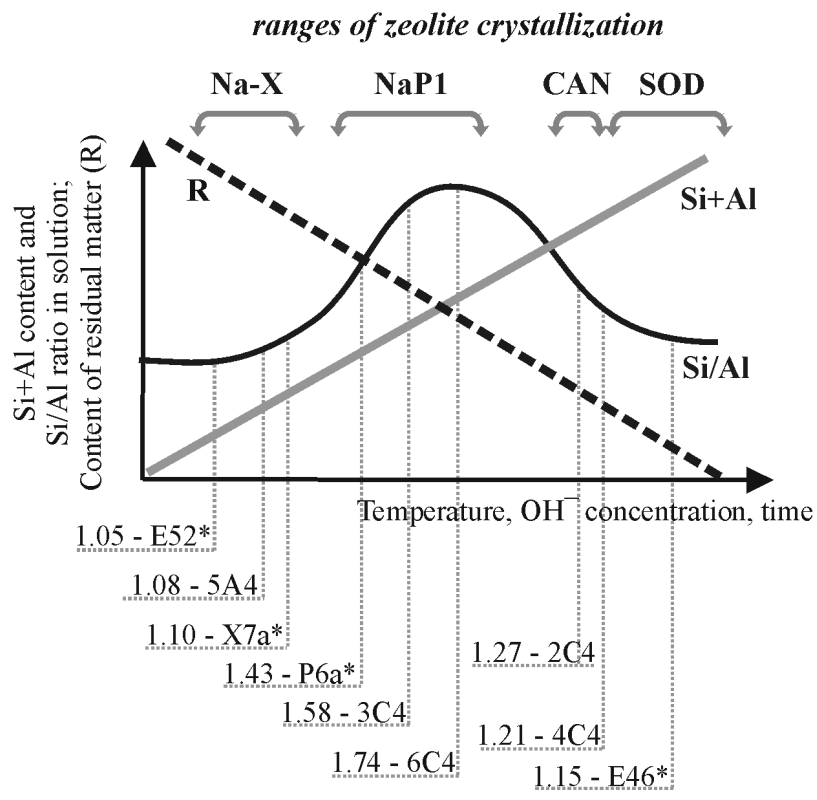

Fig. 12. Crystallization of zeolite phases in relation to reaction progress.

Changes of $\mathrm{Si}$ and $\mathrm{Al}$ due to the crystallization of new phases not been taken into account. Measured Si/Al of new phases and sample numbers are given below the plot. Asterisks indicate samples prepared under slightly different conditions than those described (Derkowski and Franus, unpublished).

$\mathrm{R}$ - residual matter contents 
$\mathrm{Si}$ is stable only as the $\left[\mathrm{Si}(\mathrm{OH})_{5}\right]^{-}$form and $\mathrm{Al}$ as the $\left[\mathrm{Al}(\mathrm{OH})_{4}\right]^{-}$form. Both complexes group into dimers with an oxygen bond and with aluminium ions surrounded by four silicate ligands - the zeolite precursors (Ermoshin et al. 1997).

The crystallization of new phases, and their compositions, probably depends on a few major solution parameters: $\mathrm{pH}, \mathrm{Si} / \mathrm{Al}$, alkali-element content and composition, and $\mathrm{Cl}^{-}$content (Breck 1974; Donahoe, Liou 1985; Cocks, Pope 1995; Lechert 1996). The results presented here may suggest an interdependence linking the nature of crystallizing phases, their $\mathrm{Si} / \mathrm{Al}$ and that of the solution, and the degree of ash dissolution. Thus, zeolite crystallization ranges, incorporated into the scheme of fly ash dissolution (Fig. 11), results in a dissolution-crystallization model (Fig. 12).

The proposed model (Fig. 12), based on the results presented here, is an empirical model. The polyphase materials, involving various crystalline-, amorphous- or partly-ordered structures, are very difficult systems to simulate theoretically. Dissolution and crystallization occur almost simultaneously, except for the initial reaction stages characterized only by dissolution and the final stage of crystallization in samples characterized by the lowest $R$ values. The processes involved may not allow an unequivocal distinction between the factors controlling selective dissolution and those that influence crystallization (and the incongruent dissolution/crystallization of new phases) in a system far-from-equilibrium and with active feedbacks. The application of a fractal dimension to the synthesis of zeolites from pure solutions suggests that such an approach might help to quantify such irregular behavior (Tatlier, Erdem-Şenatalar 1998).

\section{CONCLUSIONS}

Various zeolite phases, namely sodalite (SOD), hydroxysodalite (SOD), CAN phases, $\mathrm{Na}-\mathrm{X}$ (FAU) and NaP1 (GIS) were synthesized by alkali-hydrothermal transformation of F-class fly ash. Zeolite compositions, and the quantity of zeolite phases and residual components, vary depending on the reaction conditions.

1. A series of syntheses enabled a generalized scheme of zeolite crystallization fields to be defined. The Na-X (FAU) phase crystallizes at the lowest temperature $\left(70^{\circ} \mathrm{C}\right)$, whereas the NaP1 (GIS) phase occupies the field characterized by the highest temperature $\left(150^{\circ} \mathrm{C}\right)$ and lowest $(0.5 \mathrm{M}) \mathrm{OH}^{-}$concentration. The crystallization of SOD and CAN phases occurs at medium-high temperatures and $\geq 3 \mathrm{M} \mathrm{OH}^{-}$concentrations. With increasing $\mathrm{Cl}^{-}$concentration in solution, cancrinite/hydroxycancrinite (CAN), hydroxysodalite (SOD) and sodalite (SOD) crystallize in turn.

2. Taking the solid/liquid (ash/solution) ratio as constant, which zeolite crystallizes depends mainly on the concentration of $\mathrm{OH}^{-}$and $\mathrm{Cl}^{-}$in solution and on the reaction temperature. The duration of the reaction is of less importance. The crystallization of a given zeolite phase is related to the intensity and degree of substrates dissolution.

3. The rate of dissolution of fly ash components depends on the $\mathrm{NaOH}$ concentration and on temperature. Dissolution, favouring one or other of the reactants, leads to variation of the solution $\mathrm{Si} / \mathrm{Al}$. Variation of the solution $\mathrm{Si} / \mathrm{Al}$ may also result from 
the selective leaching of $\mathrm{Si}$ and $\mathrm{Al}$ from aluminosilicate glass. With advancing dissolution, residual-matter contents decrease and the concentrations of Si and Al ions in solution increase. Initially, amorphous glass and then quartz are dissolved causing an increase in the solution $\mathrm{Si} / \mathrm{Al}$. At the most advanced stage, mullite dissolves (and solution $\mathrm{Si} / \mathrm{Al}$ decreases). At high temperature and highest $\mathrm{NaOH}$ concentration, the ash components dissolve vigorously and simultaneously. As the reacting substrate components increasingly dissolve, $\mathrm{Na}-\mathrm{X}$ phases (solution $\mathrm{Si} / \mathrm{Al}$ 1.0), NaP1 (solution Si/Al highest at 1.9) and finally CAN and SOD phases crystallize in sequence (Fig. 12).

4. Zeolite $\mathrm{Si} / \mathrm{Al}$ values increase with rising reaction temperatures and lessening $\mathrm{NaOH}$ concentrations.

Acknowledgments. The authors thank Ewa Słaby, Jarosław Tyszka, Jan Środoń and Pádhraig Kennan for their suggestions and for reviewing the manuscript. We are grateful to Marta Labocha for her help with the statistical analyses. Anna Łatkiewicz and Michał Skiba assisted with the analyses and laboratory procedures. This work was supported by the Polish Committee for Scientific Research (KBN) grant No 6 P04D 03919.

\section{REFERENCES}

AMRHEIN CH., HAGINA G.H., KIM T.S., MOSHER P.A., GAGAJENA R.C., AMANIOS T., TORRE DE LA L., 1996: Synthesis and properties of zeolites from fly ash. Environmental Science and Technology 30, 735-742.

ARMSTRONG J.A., DANN S.E., 2000: Investigation of zeolite scales formed in the Bayer process. Microporous Mesoporous Materials 41, 89-97.

BAERLOCHER CH., MEIER W.M., OLSON D.H., 2001: Atlas of zeolite framework types. Str. Comm. IZA. 5th Revised Edition, Elsevier, London Boston Singapore Sydney Toronto Wellington.

BERKGAUT V., SINGER A., 1996: High capacity cation exchanger by hydrothermal zeolitization of coal fly ash. Applied Clay Science 10, 369-378.

BRECK D.W., 1974: Zeolite molecular sieves. Structure, chemistry, and use. John Wiley \& Sons, New York-London-Sydney-Toronto.

CHANG H.L., SHIH W.H., 1998: A general method for the conversion of fly ash into zeolites as ion exchangers for cesium. Ind. Eng. Chem. Res. 37, 71-78.

CHRISTIDIS G.E., PASPALIARIS I., KONSTANTOPOULOS A., 1999: Zeolitisation of perlite fines: mineralogical characteristics of the end products and mobilization of chemical elements. Applied Clay Science 15, 305-324.

COCKS P.A., POPE CH.G., 1995: Salt effects on the synthesis of some aluminous zeolites. Zeolites, 15, 701-707.

DERKOWSKI A., 2001: Różnorodne metody syntezy zeolitów z popiołów lotnych jako próba utylizacji odpadów paleniskowych. (Various methods of synthesis of zeolites from fly ash as an attempt of utilization of post-combustion wastes. In Polish). Przeglad Geologiczny 49, 337-338.

DERKOWSKI A., 2002a: Microwave oven in synthesis of Na-zeolites from fly ash. Preliminary results. Mineralogia Polonica 33 (1), 81-95.

DERKOWSKI A., 2002b: Experimental transformation of volcanic glass from Streda nad Bodrogom (SE Slovakia). Geologica Carpatica. 53, special issue CD.

DONAHOE R.J., LIOU J.G., 1985: An experimental study on the process of zeolite formation. Geochimica and Cosmochimica Acta 49, 2349-2360.

ERMOSHIN V.A., SMIRNOV K.S., BOUGEARD D., 1997: Ab initio study of the initial steps of hydrothermal zeolite synthesis and of sol-gel processes. Journal of Molecular Structure (Theochem) 393, 171-176. 
FIORE S., HUERTAS F.J., HUERTAS F., LINARES J., 2001: Smectite formation in ryolitic obsidian as inferred by microscopic (SEM-TEM-AEM) investigation. Clay Minerals 36, 489-500.

HARI BABU E., UPADHYA Y.D., UPADHYAY S.N., 1993: Removal of phenols from effluents by fly ash. International Journal of Environmental Studies 43, 169-176.

HOLLMAN G.C., STEENBRUGGEN G., JANSSEN-JURKOVICOVA M., 1999: A two-step process for the synthesis of zeolites from coal fly ash. Fuel 78, 1225-1230.

KAWANO M., TOMITA K., 1997: Experimental study on the formation of zeolites from obsidian by interaction with $\mathrm{NaOH}$ and $\mathrm{KOH}$ solutions at 150 and $200^{\circ} \mathrm{C}$. Clays and Clay Minerals 45, 365-377.

KOLAY P.K., SINGH D.N., 2002: Characterization of an alkali activated lagoon ash and its application for heavy metal retention. Fuel 81, 483-489.

LECHERT H., 1996: The mechanism of faujasite growth studied by crystallization kinetics. Zeolites 17, 473-482.

LINDNER T., LECHERT H., 1996: Chelate ligands as mineralizing agents in hydrothermal synthesis of faujasite-type zeolites: A kinetic study. Zeolites 16, 196-206.

ŁOMNICKI A., 2000: Wprowadzenie do statystyki dla przyrodników. (Introduction to statistics for nature researchers. In Polish). Wyd. 2. Wydawnictwo Naukowe PWN, Warszawa.

MA W.P., BROWN P.W., KOMARNENI S., 1998: Characterization and cation exchange properties of zeolite synthesized from fly ashes. Journal of Materials Research 13, 3-7.

MANZ O.E., 1999: Coal fly ash: a retrospective and future look. Fuel 78, 133-136.

MICHALIK M., WILCZYŃSKA-MICHALIK W., 1998: Synteza zeolitów z popiołów lotnych wytwarzanych w elektrowniach jako próba rozszerzenia możliwości utylizacji odpadów. (The synthesis of zeolites from electricity fly ash as an attempt of broadening of wastes utilization possibilities. In Polish). Przeglad Geologiczny 46, 421-425.

MURAYAMA N., YAMAMOTO H., SHIBATA J., 2002: Mechanism of zeolite synthesis from coal fly ash by alkali hydrothermal reaction. International Journal of Mineral Processing 64, 1-17.

OELKERS E.H., 2001: General kinetic description of multioxide silicate mineral and glass dissolution. Geochimica and Cosmochimica Acta 65, 3703-3719.

POOLE C., PRIJATAMA H., RICE N.M., 2000: Synthesis of zeolite adsorbents by hydrothermal treatment of PFA wastes: a comparative study. Minerals Engineering 13, 831-842.

QUERALT I., QUEROL X., LOPEZ-SOLER A., PLANA F., 1997: Use of coal fly ash for ceramics: a case study for a large Spanish power station. Fuel 76, 787-791.

QUEROL X., ALASTUEY A., FERNANDEZ-TURIEL J.L., LOPEZ-SOLER A., 1995: Synthesis of zeolites by alkaline activation of ferro-aluminous fly ash. Fuel 74, 1226-1231.

QUEROL X., MORENO N., UMANA J.C., ALASTUEY A., HERNANDEZ E., LÒPEZ-SOLER A., PLANA F., 2002: Synthesis of zeolites from coal fly ash: an overview. International Journal of Coal Geology 50, 413-423.

QUEROL X., PLANA F., ALASTUEY A., LOPEZ-SOLER A., 1997: Synthesis of Na-zeolites from fly ash. Fuel 76, 793-799.

RATAJCZAK T., GAWE€ A., GÓRNIAK K., MUSZYŃSKI M., SZYDŁAK T., WYSZOMIRSKI P., 1999: Charakterystyka popiołów lotnych ze spalania niektórych węgli kamiennych i brunatnych. (The characteristic of fly ashes after combustion of some of the brown and black coals. In Polish). Polskie Towarzystwo Mineralogiczne - Prace Specjalne 13, 11-34.

SARBAK Z., KRAMER-WACHOWIAK M., 1998: Structural, thermal and adsorption properties of chemically modified fly ash. Hungarian Journal of Industral Chemistry 26, 101-104.

SARBAK Z., KRAMER-WACHOWIAK M., 2002: Porous structure of waste fly ashes and their chemical modifications. Powder Technology 123, 53-58.

SHIH W.H., CHANG H.L., 1996: Conversion of fly ash into zeolites for ion-exchange applications. Materials Letters 28, 263-268.

TATLIER M., ERDEM-ŞENATALAR A., 1998: Fractal dimension as a tool to guide zeolite synthesis. Chaos, Solitons and Fractals 9, 1803-1812.

TREACY M.M.J., HIGGINS J.B., 2001: Collection of simulated XRD powder patterns for zeolites. Str. Comm. IZA. 5th Revised Edition, Elsevier, London Boston Singapore Sydney Toronto Wellington. 
TYSON R., 1997: Scientists link coal fly ash disposal to amphibian abnormalities. Environmental Science and Technology 31, 408

WILCZYŃSKA-MICHALIK W., MICHALIK M., 1996: Charakterystyka morfologiczna i chemiczna produktów spalania paliw stałych. (The morphological and chemical characteristic of solid fuels combustion products. In Polish). Aura 6, 5-6.

WIRSCHING U., 1981: Experiments on the hydrothermal formation of calcium zeolites. Clays Clay Minerals $29,171-183$.

YAN J., NERETNIEKS I., 1995: Is the glass phase dissolution rate always a limiting factor in the leaching processes of combustion residues? Science of Total Environment 172, 95-118.

Arkadiusz DERKOWSKI, Marek MICHALIK

\section{Synteza zeolitów z popiołów lotnych w ujęciu statystycznym}

\section{Streszczenie}

Niniejsza praca prezentuje syntezę zeolitów z popiołów lotnych. Popiół lotny uboczny produkt spalania węgla kamiennego - został pobrany w Elektrociepłowni Kraków. Składa się on głównie ze szkliwa glinokrzemiankowego, mullitu i kwarcu. Podczas eksperymentów przowadzonych przy użyciu autoklawu z pojemnikami z PTFE testowano efektywność reakcji w szerokim zakresie warunków hydroter malnych. Synteza zeolitów polegała na reakcji popiołu z roztworem $\mathrm{NaOH}(0,5-, 3-$ lub 5-molowym) z dodatkiem 3-molowego roztworu $\mathrm{NaCl}$, w temperaturze $70^{\circ}, 100^{\circ}$ lub $150^{\circ} \mathrm{C}$, przez 12 i 24 godziny, w stosunku popiołu do roztworu 33,3 g/L. Sodalit (struktura typu SOD), hydroksysodalit (SOD), fazy typu CAN, Na-X (FAU) i NaP1 (GIS) były strukturami zeolitowymi zidentyfikowanymi w produktach reakcji. Na podstawie szczegółowej analizy statystycznej ilościowych wyników eksperymentów i parametrów reakcji stwierdzono, że typ krystalizującego zeolitu zależy przede wszystkim od stężenia anionów $\mathrm{OH}^{-} \mathrm{i} \mathrm{Cl}^{-} \mathrm{w}$ roztworze reakcyjnym oraz od temperatury reakcji. Czas trwania reakcji, jeśli rozpatrywany jest w rzędzie wielkości kilkudziesięciu godzin, ma zdecydowanie mniejsze znaczenie. Rodzaj zeolitu krystalizującego z popiołów lotnych jest kontrolowany przez kolejność i intensywność rozpuszczania składników mineralnych popiołu. Różna kolejność rozpuszczania substratów glinokrzemianowych powoduje zmianę stosunku $\mathrm{Si} / \mathrm{Al}$ w rozworze reakcyjnym, wraz z czasem reakcji. Mullit jest najbardziej odpornym składnikiem popiołu i jego rozpuszczanie, zachodzące przy najbardziej agresywnych warunkach, powoduje obniżenie stosunku $\mathrm{Si} / \mathrm{Al}$ w roztworze. Sekwencja krystalizacji zeolitów w czasie reakcji odzwierciedla różne tempo rozpuszczania składników popiołów w czasie, a ewolucja składu chemicznego kryształów zeolitów jest skutniem zmian stosunku Si/Al w roztworze reakcyjnym. 